\title{
422. 将来のPACS化に向けたパソコン利用
}

\section{私立学校教職員共済組合}

O 浜野 純行
(Yoshiyuki Hamano)
杉淵 健造
(Kenzou Sugibuchi)

\section{下谷病院}

(Shi taya)

\author{
山崎 雅代 \\ (Masayo Yamazaki)
}

放射線科

雨宮 伸司 (Shinji Amemiya) (Masami Ohishi)

東芝ME 相沢 光広 (Mi tsuhiro Aizawa)

患者に関する情報が増加の一途をたどる今日、その管理にあったってはコンピュータシステムの辛入が必要不 可欠となってきた。当院においても、PACS化へ向けて様々な試行錯誴を行っている。今回、その中の1つの 当放射線科でのパソコン利用について報告する。

【目的】第一段階は、当放射線科での全検査に関わる情報をパソコンに管理させ、それを診断，あるいは 以後の検査に退元させる事である。利用法は、(1『読影のサポートシステム』，関心とする患者に関して、 いつ、どの様な検査を行っているのか、またその時の各種の診阯名はどの様な物であったかを提示させて診断の 一助にする。(2)『CT画像の検索用データベース』，当院では、X線CTで得られた画像をダイレクトに光デ ィスクに記録しているが、以前の検索法は台帳あるいはカルテによって行なわれていた。この方法では、見落と す事も十分に考えられる上、時間もかかる。そこで、この作業をパソコンに代行させる事にした。 (3)諸検査 におけるノート』，榆査時に過去の検查情報を活用できる様にする事で、例えば要チェックの部位、あるいは撮 影法などについてのコメントを管理しておき、このデータをフォローアップ 時などに活用する。つまり、今ま で術者個人の記憶や能力に頼っていた事をコンピュータ管理による情報の活用で、レベルアップ あるいは均一 化を、より容易に計れないだろうか、というのが狙いである。

そしてさらに、PACS化に向けての入力業務についてと、データベース構築にさいしての必要項目の検討が 必要であろうと考えた。
【機器棈成】・東芝製 パソピア1600 TS 300

$$
\text { ・" 增設ハードディスクユニット（合計磁気ディスク容星 ：40MB) }
$$$$
\text { - 使用 OS: MS-DOS ・使用 言語 : PIPS-4G }
$$

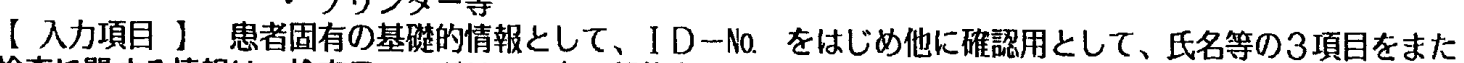
検䍒に関する情報は、検査日, モダリティ名, 部位名を、さらにCTの場合には、光ディスク№, 通算のEXA M. №. の合計 5項目となる。診断に関する情報としては、画像診断名, 鳆床診断名, 病理, 確定診断名の4 種頙の 診断名あるいは情報が入力できる様にした。現在のところ、以上の項目と備考闑について一部のデータ をコード化して入力している。

【入力方法】入力を行う者は、主として情報の発生者、すなわち検查担当者である技師あるいは医師が検査 に関する情報を、また診断担当者である医師が、診断情報を入力する事とした。

人力業務の簡素化を計る為に

(1) 一度データベースに登録した患者に関する、2回目以後の入力時には、I D-No.のみで 基礎情報を読み込む様にした。

(2) 一部のコード化データは、画面との対話式とした。

なお、誤入力防止のために I D-No.には、チェックディジットを採用した。

【対象】当放射線科における全倹査であるが、現時点での入力方法で全例入力を行う事には、無理が伴う ため、単純撮影においては選択入力を行っている。

パソコンの管理能力は、検査数で 6万6千 件余りをハードディスクに保管可能である。この数值は、決して 多いものとは言えないだろうが、当院は公称ベッド数 201床であり、全例入力を行った場合でも、約3年分 の検查数に值するのでパイロットシステムとしては、ほほ十分な物と考えている。現在、運用約10ヶ月で 2900 件余りを管理している。

検索は、I D-No.を key とする患者単位での情報提供が主体で、検索時間は15秒前後と若干遅めの仕様 となっているが、これは現時点では、このシステムの主眼をどの様な使い方，あるいは使われ方をするかによっ て内容を変更していく事に置いている為である。

【成 果】 (1)過去の情報を簡単な操作で、徒来よりスピーディに検索できる様になり、諸情報の有効活用が 容易と成った。 (2)情報の追記, 変更機能を用いた、担当者による入力を行う事で、一個人に対する入力業務の 負担が軽減できた。

なお、今後の課題の1つは、入力業務の簡略化である。当院では、現在 I BMのシステムを用いた病院情報シ ステムを構築中で、このシステムとのリンケージができれば、患者基本情報の入力は不用と成る。 また、各種 情報のコード化による入力業務と検索能の検討も重要な要素であり、対応を娭討中である。

現時点では、まだまだ不十分なこのパイロットシステムを、将来的にはR I Sに発展させる基整にしたい、と 考えている。 